\title{
Effect of Casein and Hydrocolloid on Maize Dough and Chapati Properties
}

\author{
Manju Bala ${ }^{1 *}$, Arun Kumar ${ }^{2}$, S.K. Nanda ${ }^{1}$ and R.K. Gupta ${ }^{1}$ \\ ${ }^{1}$ ICAR-Central Institute of Post-Harvest Engineering and Technology, PAU, \\ Ludhiana-141 004, Punjab, India \\ ${ }^{2}$ ICAR-Indian Agricultural Research Institute, Pusa, New Delhi-110 012, India \\ *Corresponding author
}

\section{A B S T R A C T}

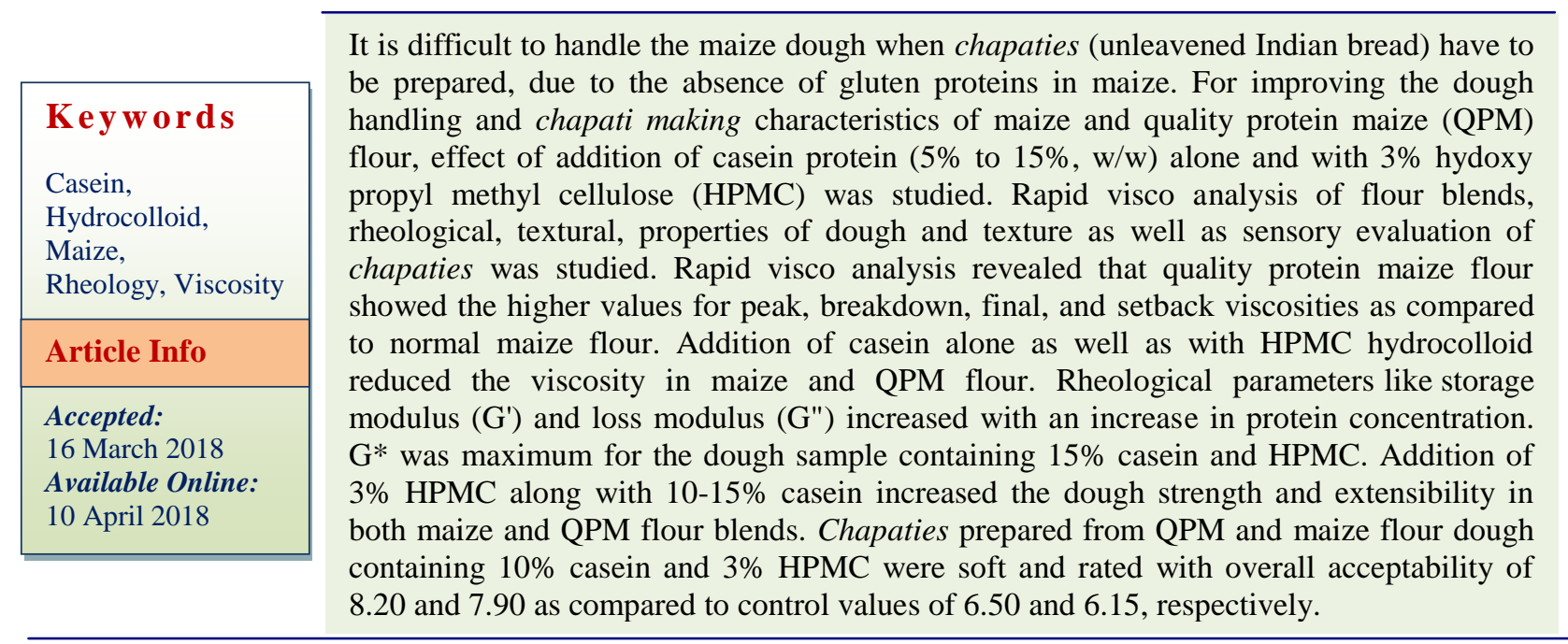

\section{Introduction}

More and more people are being diagnosed with gluten intolerance/ celiac disease. Such people who have allergy to gluten cannot take foods developed from cereals viz. wheat, rye, barley, kamut, spelt, oats, triticale etc. The only treatment to this disease is to avoid products containing gluten proteins. To tackle with the problem of celiac disease variety of grains are utilized. The most commonly used cereal flours are of rice, sorghum, maize, millets etc.
The absence of gluten produces technological problems in the development of dough as well as product. To solve these technological problems, several additives have been tried which could mimic gluten properties (Sciarini et al., 2012). Keeping in view that gluten free products are usually developed from so to improve their nutritional value proteins from different sources have been added by different workers, which not only resulted in nutritional benefits but also improved volume, appearance and sensory aspects of the products. However, although initially the aim 
of addition of proteins was to increase the nutritional value of gluten free products, lately, it has been reported that the formation of a continuous protein phase is vital for obtaining an improvement in the quality of gluten free products (Matos et al., 2014). Therefore, the selection of the protein source with the appropriate functionality seems to play an important role in the production of gluten free products. Moreover, hyrdocolloids such as carboxymethylcellulose (CMC) and hydroxypropylmethylcellulose (HPMC) and water combinations have been reported to replace gluten in the rice based breads (Ylimaki et al., 1988). Saha and Bhattacharya, 2010; Dixit and Bhattacharya, 2015 have shown that rheological properties of rice dough can be modified by addition of protein and /or hydrocolloid.

In India, maize (Zea mays L.) has emerged as the third important food grain crop after wheat and rice. It is mainly utilized as a source of human food (25\%), animal feed (12\%), poultry feed (49\%), industrial products mainly as starch $(12 \%)$, and $1 \%$ each in brewery and as seed out of the total maize produce in India (Dass et al., 2008). Majority of the people living in the Indian subcontinent depend on unleavened bread known as chapati. Maize flour is used to make unleavened bread (chapati), which is mainly consumed in a few Northern states of India (Sandhu et al., 2007). QPM is a special variety of maize which has twice the amount of lysine and tryptophan than normal maize. Maize as well as QPM is a gluten free cereal, thus suitable to produce foods addressed to celiac patients. The utilization of maize as well as QPM for making chapaties shows difficulty as it does not form viscoelastic dough on kneading. Understanding of the dough rheology is an important parameter for handling with respect to sheeting or rolling particularly with chapaties. Keeping in view that sheeting of maize chapati with rolling pin is difficult so in order to improve dough handling characteristics of maize and QPM flour the present study was conducted to study the effect of casein protein at different concentrations along with hydrocolloid (3\% HPMC) on a) dough rheology and texture b) on texture, sensory and nutritional characteristics of chapaties.

\section{Materials and Methods}

\section{Raw materials}

Quality protein maize (HQPM-5) and maize (HM-4) were procured from department of plant breeding, ICAR-Indian Institute of Maize Research, Ludhiana. The grains of QPM and maize were cleaned and pulverized into fine flour (Sieve Mesh No. 40 BSS; $0.401 \mathrm{~mm}$ ). The flour was packaged in air tight containers till further use. The proximate composition of the flour was determined by AOAC (2000). Quality protein maize flour contained $7.00 \mathrm{~g} / 100 \mathrm{~g}$ moisture, $9.33 \mathrm{~g} / 100 \mathrm{~g}$ protein, $4.50 \mathrm{~g} / 100 \mathrm{~g}$ crude fat, $1.33 \mathrm{~g} / 100 \mathrm{~g}$ minerals, $77.84 \mathrm{~g} / 100 \mathrm{~g}$ carbohydrates while maize flour had $6.91 \mathrm{~g} / 100 \mathrm{~g}$ moisture, 9.28 $\mathrm{g} / 100 \mathrm{~g}$ protein, $4.07 \mathrm{~g} / 100 \mathrm{~g}$ crude fat, 1.45 $\mathrm{g} / 100 \mathrm{~g}$ minerals and $79.29 \mathrm{~g} / 100 \mathrm{~g}$ carbohydrates.

\section{Pasting properties of flour with and without additives}

Pasting properties were determined using a rapid visco analyzer (RVA) (Newport Scientific model 4-SA, Warriewood, Australia) by following the AACC Approved Method No. 61-02 (AACC, 1995). The QPM and maize flour blend suspension was prepared by mixing $3.5 \mathrm{~g}$ flour blend sample (14 g/100 g moisture basis) with $25 \mathrm{ml}$ distilled water in an aluminum canister. Different parameters viz. peak viscosity, final viscosity, breakdown (Peak viscosity- trough viscosity) and setback (difference between 
final viscosity - trough viscosity) were determined. Trough viscosity is defined as minimum viscosity at $95^{\circ} \mathrm{C}$. Viscosity values were taken in $\mathrm{cP}$.

\section{Dynamic oscillatory measurements}

A controlled stress/strain rheometer (Paar Physica rheometer, MCR 301, Anton Paar $\mathrm{GmbH}$, Germany) was used to determine dynamic rheological measurements of the dough. The equipment was fitted with parallel plate geometry (50 mm diameter, $1 \mathrm{~mm}$ gap). The maize and QPM dough samples were placed between the plates and after 5 min resting time was given before starting the test. The rim of the sample was coated with paraffin oil in order to prevent evaporation during the measurements. All the measurements were performed at a temperature of $25^{\circ} \mathrm{C}$. In order to determine the linear viscoelastic region (LVE) the strain sweeps at $1 \mathrm{~Hz}$ frequency were carried out from 0.01 to $100 \%$ at temperature $25^{\circ} \mathrm{C}$. Frequency sweep tests were performed from 0.01 to $10 \mathrm{~Hz}$ to determine the storage modulus ( $\left.\mathrm{G}^{\prime}\right)$, loss modulus (G') and loss tangent $(\tan )$ as a function of frequency. Two replicates of each measurement were made.

\section{Dough extensibility and Chapati making properties of QPM and Maize flour}

Dough extensibility study was done using Kieffer rig on TA/XT2 Texture analyzer (Stable Micro Systems, Surrey, England). QPM and maize flour $90 \mathrm{~g}$ was mixed with $90 \mathrm{ml}$ of water for $3 \mathrm{~min}$ in lab mixer. The dough was rested for half an hour. For preparing chapaties $30 \mathrm{~g}$ of dough sample was rounded and rolled in the form of chapati up to a diameter of $140 \mathrm{~mm}$ and thickness of $2 \mathrm{~mm}$. Chapati was baked as per method of Sandhu et al., 2007. The chapati was allowed to cool for $10 \mathrm{~min}$ at $25^{\circ} \mathrm{C}$ and then placed in polythene pouches and placed in air tight containers at $25^{\circ} \mathrm{C}$. Rectangular strips of $7 \mathrm{x}$ $1.5 \mathrm{~cm}$ were cut from the centre of the chapati using a metal template. This strip of chapati was then tested for extensibility on the TA/XT2 Texture analyzer (Stable Micro Systems, Surrey, England). One clamp was attached to the moving arm of TA/XT2 and the other was attached to the platform. A load cell of $50 \mathrm{~N}$ was used at a cross head speed of $1 \mathrm{~mm} / \mathrm{s}$ to pull the chapati strip apart until it ruptured. From the force displacement curve peak force to rupture $(\mathrm{N})$ and extensibility (mm) were calculated.

\section{Sensory evaluation and proximate analysis}

The sensory characteristics of chapaties were evaluated by the sensory panel comprised of 15 semi trained persons aged between 25 and 50. All of the samples were coded with random 3 digit numbers before presenting to the panel. The panel was provided with chapaties two in number for every experimental sample and asked to score them for different sensory attributes. Water was provided to the panelists for rinsing the mouth in between the evaluation of different samples. Nine point hedonic scale was used to evaluate the sensory characteristics such as appearance, texture, flavor, taste and overall acceptability for all the chapati samples. (BIS, 1971). The chapati samples prepared from QPM and maize flour were studied by the AOAC (2000) methods, for moisture, crude fat, protein and total ash content. For this the chapati was crumbled, mixed uniformly and known weight of the mixed material was taken to represent the whole chapati. Three samples were used as replicate each time.

\section{Statistical analysis}

Statistical analysis was done using SPSS software, Version 16.0 (Pascal International Software Solution, Boston, MA, USA). The effect of casein protein and HPMC on pasting 
profile of flour, rheological properties of the dough and textural properties of dough, and chapati, nutritional and sensory properties of the chapaties was studied using one-way ANOVA, and means were compared using least significant difference (LSD).

\section{Results and Discussion}

\section{Pasting properties of flour blends}

Pasting characteristics of maize and QPM flour and the blends with casein and HPMC are shown in Table 1. Significant differences in the pasting properties of QPM, normal maize flours and flours with added casein and HPMC were observed. The pasting profiles could be explained based on molecular characteristics of the starch components such as amylose or amylopectin contents (Nimsung et al., 2007). QPM flour showed substantially higher peak, breakdown, setback, and final viscosity than that of normal maize flour. This could be due to the varietal difference. Moreover, the differences in the size and shape of starch granules could have the effect on pasting profiles.

The peak viscosity (PV) of starch paste has been reported to be an important characteristic to distinguish a given starch from the other species of starch (Huang et al., 2006). Significant variation in PV between maize and QPM shows differences in their starch. Tester and Morrison (1990) reported that the pasting properties of starch are affected by amylose, lipid content and branch chain length distribution of amylopectin. The observed variation might be due to changes in the structure of the starch components i.e. branch chain length distribution of amylopectin.

Pasting temperature (PT) provides an indication of the minimum temperature required to cook the flour. Results revealed that there is no significant difference between the PT of maize and QPM. Pasting temperature for the flour blends ranged from 78.10 to $79.83{ }^{\circ} \mathrm{C}$. PT increased with addition of HPMC. It could be due to the reason that hydrocolloid may compete with prime starch chains and may be responsible for raising gelatinization temperature.

Addition of casein significantly reduced the viscosities in both flours. Viscosities further dropped down when the flour blends with casein were supplemented with HPMC. This negative influence of protein and hydrocolloids could be due to dilution of starch component. Increasing concentration of protein may compete with starch granules for water absorption and thus cause hindrance in the swelling of starch granules (Nimsung et al., 2007). Similar decrease in viscosity with addition of different concentration of whey protein concentrate in water chestnut flour has been reported by Sarabhai and Prabhasankar (2015).

Breakdown viscosity (BV) for different flour blends varied from 93.67 to $607.67 \mathrm{cP}$. BV expresses the ability of starches to withstand heating at high temperature and shear stress.BV of QPM was more than maize flour. Higher BV may be due to the presence of increased number of shorter amylopectin branch chains (Patindol et al., 2005).

A negative correlation between long chains of amylopectin and breakdown viscosity has been reported by Han and Hamaker (2001). A greater proportion of short branched chain amylopectin may result in swollen, more breakable starch granules. Maize flour with $15 \%$ protein and 3\% HPMC showed the least breakdown among all the studied samples. The lowest BV of maize flour blend indicated its high paste stability under heat and shear.

During the final cycle of cooling viscosity increased further in all samples. This increase 
in viscosity could be due to the alignment of amylose chains (Flores-Farias et al., 2000). During the cooling cycle, the viscosity of all starch pastes increased rapidly because of the large number of intermolecular hydrogen bonds that were formed, resulting in gel formation at lower temperatures (Leelavathi et al., 1987).

Setback viscosity (SV) of QPM and maize flour decreased from 1681.7 to $769 \mathrm{cP}$ and 931.3 to $455.3 \mathrm{cP}$, respectively, the lowest was observed for maize flour blend with $15 \%$ casein and 3\% HPMC and the highest for QPM flour. The lowest SV of flour indicated its lower tendency to retrograde. QPM displayed a higher SV indicating a higher retrogradation tendency than the maize which might be due to the effect of amylose and amylopectin composition. Starch with high amylose could undergo the retrogradation process faster than the starch with low amylose content. Yam starches gave a higher setback indicating a higher retrogradation tendency. This was most likely due to the greater amount of amylase present, which resulted in the shorter amylose chains causing intermolecular association, thus producing retrogradation (Hoover and Sosulski, 1991). Starch retrogradation is the process, which occurs when the molecular chains in gelatinized starches begin to re-associate in an ordered structure (Sandhu and Singh, 2007). During retrogradation; amylose forms doublehelical associations of 40-70 glucose units while amylopectin crystallization occurs by re-association of the outermost short branches.

The RVA data provided useful information for food processing and product development. QPM displayed very high viscosities which is desirable for the products such as breads for increased texture quality. However, addition of casein and HPMC had significantly reduced the viscosities to the tune that is well below the levels of normal maize flour.

\section{Dynamic oscillatory measurements}

\section{Amplitude sweep}

The viscoelastic properties of the maize and QPM dough containing casein at different levels $(5,10,15 \%)$ as well as with addition of HPMC (3\%) and control samples were studied by dynamic oscillatory test. Small amplitude measurements not only provides information about microstructure of samples under study, but also distinguishes weak gels from strong gels and gives information about their linear viscoelastic (LVE) region. The amplitude sweep test of maize and QPM flour blends, at various concentration of casein, with and without hydrocolloids was carried out at fixed temperature of $25^{\circ} \mathrm{C}$ and frequency of $1 \mathrm{~Hz}$. $\mathrm{LVE}$ region was found to be limited up to a strain of $0.1 \%$.

The results revealed that the tau values for maize and QPM ranged from 109-111 and 158-163, respectively. Both maize as well as QPM dough showed LVE upto $0.1 \%$ strain only showing them to be weak gels as it has been reported that strong gels remain in the linear viscoelastic region over greater strains than weak gels (Steffe, 1996).

\section{Frequency sweep}

In order to evaluate material specification and comparison of viscoelastic behavior of different dough formulations, the frequency sweep test was carried out at $25^{\circ} \mathrm{C}$, at a strain of $0.1 \%$ and frequency range of 0.1 to $10 \mathrm{~Hz}$. Frequency sweep gives information about how the viscous and elastic behavior of the sample changes with rate of applied strain at a constant amplitude (Steffe, 1996). Elastic or storage modulus $\left(G^{\prime}\right)$ and viscous or loss modulus $\left(G^{\prime \prime}\right)$ represents the non-dissipative (elastic) and dissipative part (viscous flow) of the mechanical properties of the material under study. 
Table.1 Pasting characteristics of maize and quality protein maize blends

\begin{tabular}{|c|c|c|c|c|c|c|}
\hline & PV (cP) & BV(cP) & FV(cP) & SV(cP) & $\mathbf{P}_{\mathrm{T}}$ (Min) & $\mathbf{T}_{\mathbf{P}}\left({ }^{\circ} \mathbf{C}\right)$ \\
\hline M control & $1005.00^{\mathrm{t}}$ & $307.00^{d}$ & $1629.33^{\mathrm{e}}$ & $931.33^{\mathrm{e}}$ & $4.65^{\mathrm{bcd}}$ & $78.15^{b}$ \\
\hline $\mathrm{M}+5 \% \mathrm{C}$ & $770.67^{\mathrm{h}}$ & $211.67^{\mathrm{e}}$ & $1260.33^{h}$ & $706.67^{\mathrm{h}}$ & $4.55^{\mathrm{cdfg}}$ & $78.77^{\mathrm{ab}}$ \\
\hline $\mathrm{M}+10 \% \mathrm{C}$ & $610.67^{j}$ & $196.33^{\mathrm{ef}}$ & $954.00^{\mathrm{k}}$ & $533.67^{j}$ & $4.45^{\mathrm{g}}$ & $78.68^{\mathrm{ab}}$ \\
\hline$M+15 \% C$ & $534.33^{\mathrm{k}}$ & $162.00^{\mathrm{g}}$ & $833.67^{1}$ & $454.33^{\mathrm{k}}$ & $4.45^{\mathrm{g}}$ & $79.08^{\mathrm{ab}}$ \\
\hline $\mathrm{M}+5 \% \mathrm{C}+3 \% \mathrm{H}$ & $680.00^{\mathrm{i}}$ & $114.33^{\mathrm{h}}$ & $1171.00^{\mathrm{i}}$ & $636.67^{i}$ & $4.60^{\mathrm{bcdf}}$ & $78.45^{b}$ \\
\hline $\mathrm{M}+10 \% \mathrm{C}+3 \% \mathrm{H}$ & $560.67^{\mathrm{k}}$ & $106.00^{\mathrm{hi}}$ & $1032.00^{\mathrm{j}}$ & $559.00^{\mathrm{j}}$ & $4.51^{\mathrm{tg}}$ & $78.78^{\mathrm{ab}}$ \\
\hline $\mathrm{M}+15 \% \mathrm{C}+3 \% \mathrm{H}$ & $438.00^{1}$ & $93.67^{1}$ & $839.00^{1}$ & $455.33^{\mathrm{k}}$ & $4.51^{\mathrm{fg}}$ & $79.03^{\mathrm{ab}}$ \\
\hline Q control & $1650.33^{\mathrm{a}}$ & $607.67^{a}$ & $2769.33^{\mathrm{a}}$ & $1681.67^{\mathrm{a}}$ & $4.78^{\mathrm{a}}$ & $78.43^{b}$ \\
\hline $\mathrm{Q}+5 \% \mathrm{C}$ & $1351.33^{b}$ & $449.00^{b}$ & $2207.67^{b}$ & $1282.67^{b}$ & $4.62^{\mathrm{bcd}}$ & $78.10^{b}$ \\
\hline$Q+10 \% C$ & $1184.00^{c}$ & $447.00^{b}$ & $1694.67^{\mathrm{d}}$ & $1052.33^{\mathrm{d}}$ & $4.49^{\mathrm{fg}}$ & $78.50^{b}$ \\
\hline$Q+15 \% C$ & $1063.00^{e}$ & $395.33^{c}$ & $1565.33^{f}$ & $884.00^{f}$ & $4.53^{\mathrm{dfg}}$ & $78.48^{b}$ \\
\hline $\mathrm{Q}+5 \% \mathrm{C}+3 \% \mathrm{H}$ & $1112.67^{\mathrm{d}}$ & $188.67^{f}$ & $2031.00^{c}$ & $1127.00^{c}$ & $4.71^{\mathrm{ab}}$ & $78.97^{\mathrm{ab}}$ \\
\hline $\mathrm{Q}+10 \% \mathrm{C}+3 \% \mathrm{H}$ & $958.00^{\mathrm{g}}$ & $203.00^{\mathrm{ef}}$ & $1655.00^{\mathrm{de}}$ & $907.33^{\mathrm{ef}}$ & $4.69^{a b}$ & $79.25^{\mathrm{ab}}$ \\
\hline $\mathrm{Q}+15 \% \mathrm{C}+3 \% \mathrm{H}$ & $777.00^{\mathrm{h}}$ & $104.33^{\text {hi }}$ & $1421.67^{g}$ & $769.00^{\mathrm{g}}$ & $4.67^{\mathrm{abc}}$ & $79.83^{\mathrm{a}}$ \\
\hline
\end{tabular}

M: Maize; Q: QPM; C: Casein; H: Hydroxy propyl methyl cellulose; $\mathrm{T}_{\mathrm{p}}$ : pasting temperature; $\mathrm{P}_{\mathrm{T}}$ : pasting time; PV, FV, BV and SV: peak, final, breakdown and setback viscosity, respectively. Values are mean of three replications. Values bearing same superscript do not differ significantly $(\mathrm{p}<0.05)$.

Table.2 QPM, maize based dough and chapati Texture studies and their sensory evaluation

\begin{tabular}{|c|c|c|c|c|c|}
\hline & \multicolumn{2}{|c|}{ Dough characteristics } & \multicolumn{3}{|c|}{ Chapati characteristics } \\
\hline & $\begin{array}{c}\text { Extensibility } \\
\quad(\mathrm{mm})\end{array}$ & $\begin{array}{l}\text { Rupture } \\
\text { force (g) }\end{array}$ & $\begin{array}{c}\text { Extensibility } \\
\text { (mm) }\end{array}$ & $\begin{array}{l}\text { Hardness } \\
\text { (g) }\end{array}$ & $\begin{array}{l}\text { Sensory } \\
\text { score }\end{array}$ \\
\hline M control & $4.59^{c} \pm 0.64$ & $5.6^{\mathrm{def}} \pm 0.33$ & $4.21^{\mathrm{a}} \pm 0.45$ & $5.4^{\mathrm{a}} \pm 0.20$ & $6.15^{\mathrm{c}} \pm 0.38$ \\
\hline $\mathrm{M}+5 \% \mathrm{C}$ & $4.16^{c} \pm 0.35$ & $7.65^{\mathrm{ab}} \pm 0.13$ & $3.91^{\mathrm{a}} \pm 0.40$ & $3.6^{\mathrm{b}} \pm 0.35$ & $6.55^{c} \pm 0.44$ \\
\hline $\mathrm{M}+10 \% \mathrm{C}$ & $3.51^{c} \pm 0.32$ & $7.75^{\mathrm{a}} \pm 0.17$ & $3.81^{\mathrm{a}} \pm 0.20$ & $3.4^{\mathrm{b}} \pm 0.12$ & $6.30^{c} \pm 0.26$ \\
\hline$M+15 \% C$ & $3.61^{c} \pm 0.67$ & $7.8^{\mathrm{a}} \pm 0.15$ & $3.21^{\mathrm{a}} \pm 0.15$ & $2.6^{\mathrm{cd}} \pm 0.17$ & $6.85^{\mathrm{b}} \pm 0.70$ \\
\hline $\mathrm{M}+5 \% \mathrm{C}+3 \% \mathrm{H}$ & $10.19^{\mathrm{a}} \pm 0.30$ & $6.9^{c} \pm 0.17$ & $3.51^{\mathrm{a}} \pm 0.37$ & $2.6^{\mathrm{cd}} \pm 0.20$ & $6.60^{\mathrm{bc}} \pm 0.25$ \\
\hline $\mathrm{M}+10 \% \mathrm{C}+3 \% \mathrm{H}$ & $10.11^{\mathrm{a}} \pm 0.73$ & $7.8^{\mathrm{a}} \pm 0.13$ & $3.61^{\mathrm{a}} \pm 0.31$ & $2.8^{\mathrm{cd}} \pm 0.40$ & $7.90^{\mathrm{a}} \pm 0.40$ \\
\hline $\mathrm{M}+15 \% \mathrm{C}+\mathbf{3} \% \mathrm{H}$ & $9.20^{\mathrm{ab}} \pm 0.67$ & $7.5^{\mathrm{ab}} \pm 0.33$ & $3.44^{\mathrm{a}} \pm 0.06$ & $2.7^{\mathrm{cd}} \pm 0.12$ & $7.35^{\mathrm{a}, \mathrm{b}} \pm 0.60$ \\
\hline Q control & $4.45^{\mathrm{c}} \pm 0.45$ & $5.1^{\mathrm{f}} \pm 0.25$ & $4.73^{a} \pm 0.21$ & $5.4^{\mathrm{a}} \pm 0.20$ & $6.50^{b c} \pm 0.68$ \\
\hline$Q+5 \% C$ & $3.74^{c} \pm 0.68$ & $5.9^{c} \pm 0.26$ & $4.15^{\mathrm{a}} \pm 0.33$ & $3.1^{\mathrm{bc}} \pm 0.36$ & $6.40^{c} \pm 0.94$ \\
\hline $\mathrm{Q}+\mathbf{1 0 \% \mathrm { C }}$ & $3.27^{\mathrm{c}} \pm 0.44$ & $7.4^{\mathrm{ab}} \pm 0.15$ & $3.83^{\mathrm{a}} \pm 0.60$ & $2.7^{\mathrm{cd}} \pm 0.12$ & $6.48^{b c} \pm 0.60$ \\
\hline$Q+15 \% C$ & $3.21^{\mathrm{c}} \pm 0.67$ & $7.1^{\mathrm{bc}} \pm 0.18$ & $4.68^{\mathrm{a}} \pm 0.38$ & $2.3^{d} \pm 0.15$ & $7.10^{b, c} \pm 0.52$ \\
\hline $\mathrm{Q}+5 \% \mathrm{C}+3 \% \mathrm{H}$ & $9.06^{\mathrm{ab}} \pm 0.30$ & $5.8^{\mathrm{de}} \pm 0.50$ & $4.47^{\mathrm{a}} \pm 0.66$ & $2.2^{\mathrm{d}} \pm 0.10$ & $6.20^{c} \pm 0.75$ \\
\hline $\mathrm{Q}+10 \% \mathrm{C}+3 \% \mathrm{H}$ & $8.93^{\mathrm{ab}} \pm 0.73$ & $7.1^{\mathrm{bc}} \pm 0.14$ & $4.53^{a} \pm 0.23$ & $2.3^{\mathrm{d}} \pm 0.15$ & $8.20^{\mathrm{a}} \pm 0.63$ \\
\hline $\mathrm{Q}+15 \% \mathrm{C}+3 \% \mathrm{H}$ & $8.58^{b} \pm 0.67$ & $7.0^{b c} \pm 0.17$ & $4.00^{\mathrm{a}} \pm 0.10$ & $2.2^{\mathrm{d}} \pm 0.06$ & $7.25^{b} \pm 0.68$ \\
\hline
\end{tabular}

M: Maize; Q: QPM; C: Casein; H: Hydroxy propyl methyl cellulose. Values are mean of three replications. Values bearing same superscript do not differ significantly $(\mathrm{p}<0.05)$. 
Table.3 Proximate composition of chapaties prepared from maize and quality protein maize flour blends

\begin{tabular}{|c|c|c|c|c|c|}
\hline Sample & Moisture & Protein & Fat & Ash & Total Carbohydrates \\
\hline M control & $31.54(0.19)^{\mathrm{h}}$ & $3.10(0.10)^{\mathrm{e}}$ & $4.13(0.15)^{\mathrm{ab}}$ & $0.92(0.01)^{\mathrm{ef}}$ & $60.30(0.09)^{\mathrm{a}}$ \\
\hline $\mathrm{M}+5 \% \mathrm{C}$ & $37.43(0.93)^{\mathrm{bc}}$ & $4.91(0.31)^{\mathrm{d}}$ & $3.65(0.17)^{\mathrm{c}}$ & $0.92(0.01)^{\mathrm{fg}}$ & $53.09(1.35)^{\mathrm{cde}}$ \\
\hline $\mathrm{M}+10 \% \mathrm{C}$ & $35.17(0.10)^{\mathrm{fg}}$ & $8.01(0.14)^{b c}$ & $3.28(0.08)^{\mathrm{c}}$ & $0.90(0.01)^{g}$ & $52.65(0.19)^{\mathrm{def}}$ \\
\hline$M+15 \% C$ & $34.45(0.48)^{\mathrm{g}}$ & $9.68\left(0.16^{a}\right.$ & $3.19(0.27)^{\mathrm{c}}$ & $1.02(0.01)^{\mathrm{bc}}$ & $51.66(0.51)^{\mathrm{fg}}$ \\
\hline $\mathrm{M}+5 \% \mathrm{C}+3 \% \mathrm{H}$ & $35.67(0.21)^{\mathrm{ef}}$ & $4.47(0.24)^{\mathrm{d}}$ & $3.62(0.19)^{b c}$ & $0.91(0.01)^{\mathrm{fg}}$ & $54.94(0.49)^{\mathrm{b}}$ \\
\hline $\mathrm{M}+10 \% \mathrm{C}+3 \% \mathrm{H}$ & $36.63(0.18)^{\mathrm{de}}$ & $7.57(0.26)^{b c}$ & $3.25(0.05)^{\mathrm{c}}$ & $0.94(0.02)^{\mathrm{de}}$ & $51.91(0.30)^{\mathrm{efg}}$ \\
\hline $\mathrm{M}+15 \% \mathrm{C}+3 \% \mathrm{H}$ & $35.47(0.15)^{\mathrm{ef}}$ & $9.62(0.16)^{\mathrm{a}}$ & $3.20(0.13)^{\mathrm{c}}$ & $0.99(0.01)^{c}$ & $50.72(0.12)^{\mathrm{g}}$ \\
\hline Q control & $32.07(0.43)^{\mathrm{h}}$ & $3.37(0.32)^{\mathrm{e}}$ & $4.25(0.05)^{\mathrm{a}}$ & $1.01(0.01)^{\mathrm{bc}}$ & $59.31(0.31)^{\mathrm{a}}$ \\
\hline $\mathrm{Q}+5 \% \mathrm{C}$ & $36.77(0.25)^{\mathrm{cd}}$ & $4.62(0.24)^{\mathrm{d}}$ & $3.30(0.23)^{\mathrm{c}}$ & $1.02(0.01)^{\mathrm{bc}}$ & $54.29(0.71)^{\mathrm{bc}}$ \\
\hline$Q+10 \% C$ & $37.97(0.45)^{b}$ & $8.28(0.19)^{\mathrm{b}}$ & $3.37(0.13)^{\mathrm{c}}$ & $1.05(0.01)^{\mathrm{a}}$ & $49.34(0.56)^{\mathrm{h}}$ \\
\hline$Q+15 \% C$ & $38.17(0.29)^{b}$ & $9.73(0.21)^{\mathrm{a}}$ & $3.25(0.23)^{c}$ & $1.03(0.02)^{\mathrm{ab}}$ & $47.82(0.34)^{\mathrm{i}}$ \\
\hline $\mathrm{Q}+5 \% \mathrm{C}+3 \% \mathrm{H}$ & $37.53(0.30)^{\mathrm{bc}}$ & $4.37(0.15)^{\mathrm{d}}$ & $3.31(0.18)^{\mathrm{c}}$ & $0.91(0.01)^{\mathrm{fg}}$ & $53.85(0.36)^{\mathrm{bcd}}$ \\
\hline $\mathrm{Q}+10 \% \mathrm{C}+3 \% \mathrm{H}$ & $39.31(0.55)^{\mathrm{a}}$ & $8.03(0.06)^{\mathrm{bc}}$ & $3.23(0.24)^{\mathrm{c}}$ & $0.96(0.01)^{\mathrm{d}}$ & $48.46(0.43)^{\mathrm{hi}}$ \\
\hline $\mathrm{Q}+15 \% \mathrm{C}+3 \% \mathrm{H}$ & $38.22(0.21)^{\mathrm{b}}$ & $9.50(0.30)^{\mathrm{a}}$ & $3.37(0.31)^{\mathrm{c}}$ & $0.95(0.01)^{\mathrm{de}}$ & $47.96(0.40)^{\mathrm{i}}$ \\
\hline
\end{tabular}

M: Maize; Q: QPM; C: Casein; H: Hydroxy propyl methyl cellulose. Values are mean of three replications. Values bearing same superscript do not differ significantly $(\mathrm{p}<0.05)$.

Fig.1 Frequency sweep analysis of QPM flour dough information about G' and G"

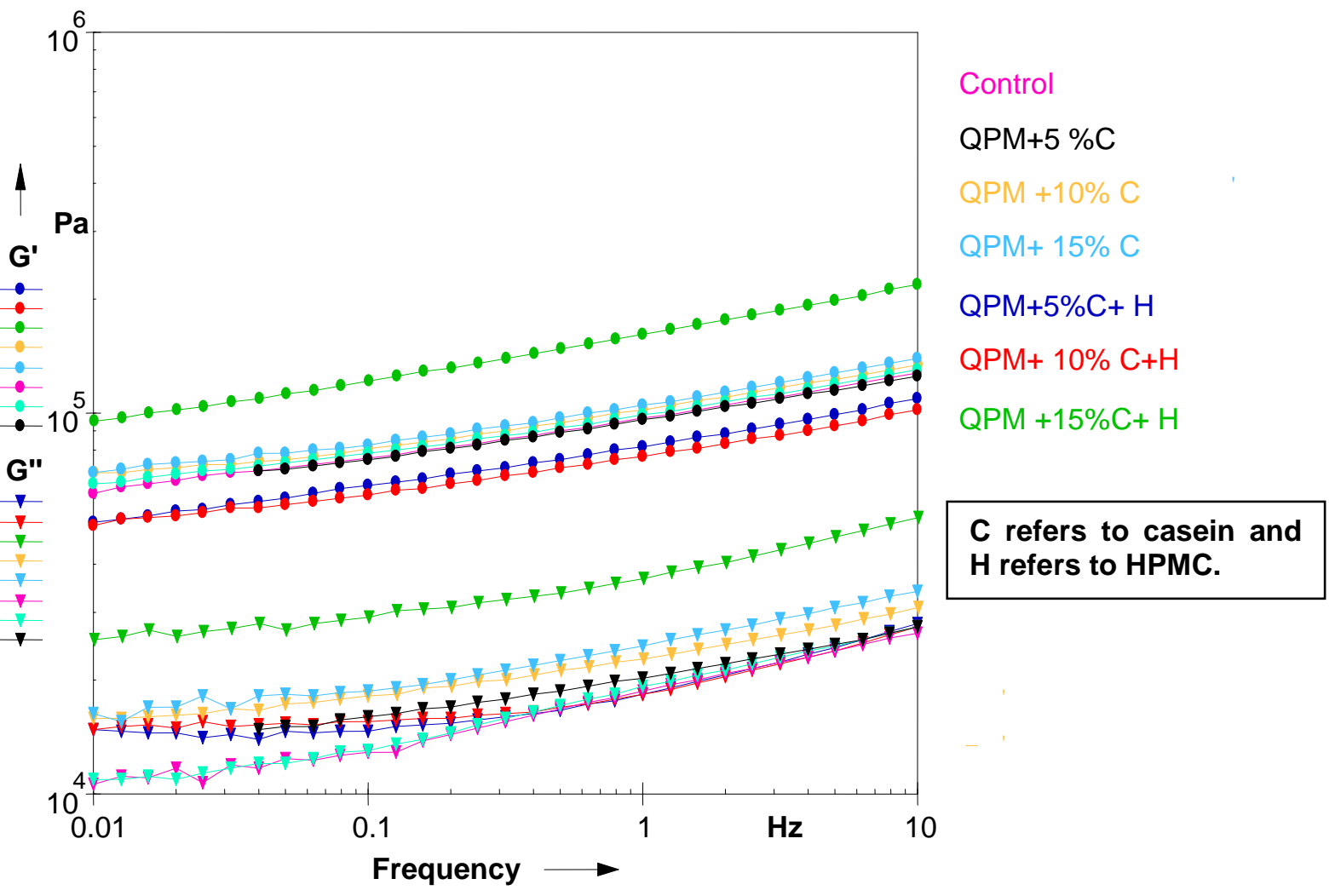


Fig.2 Frequency sweep analysis of maize flour dough giving information about G' and G"

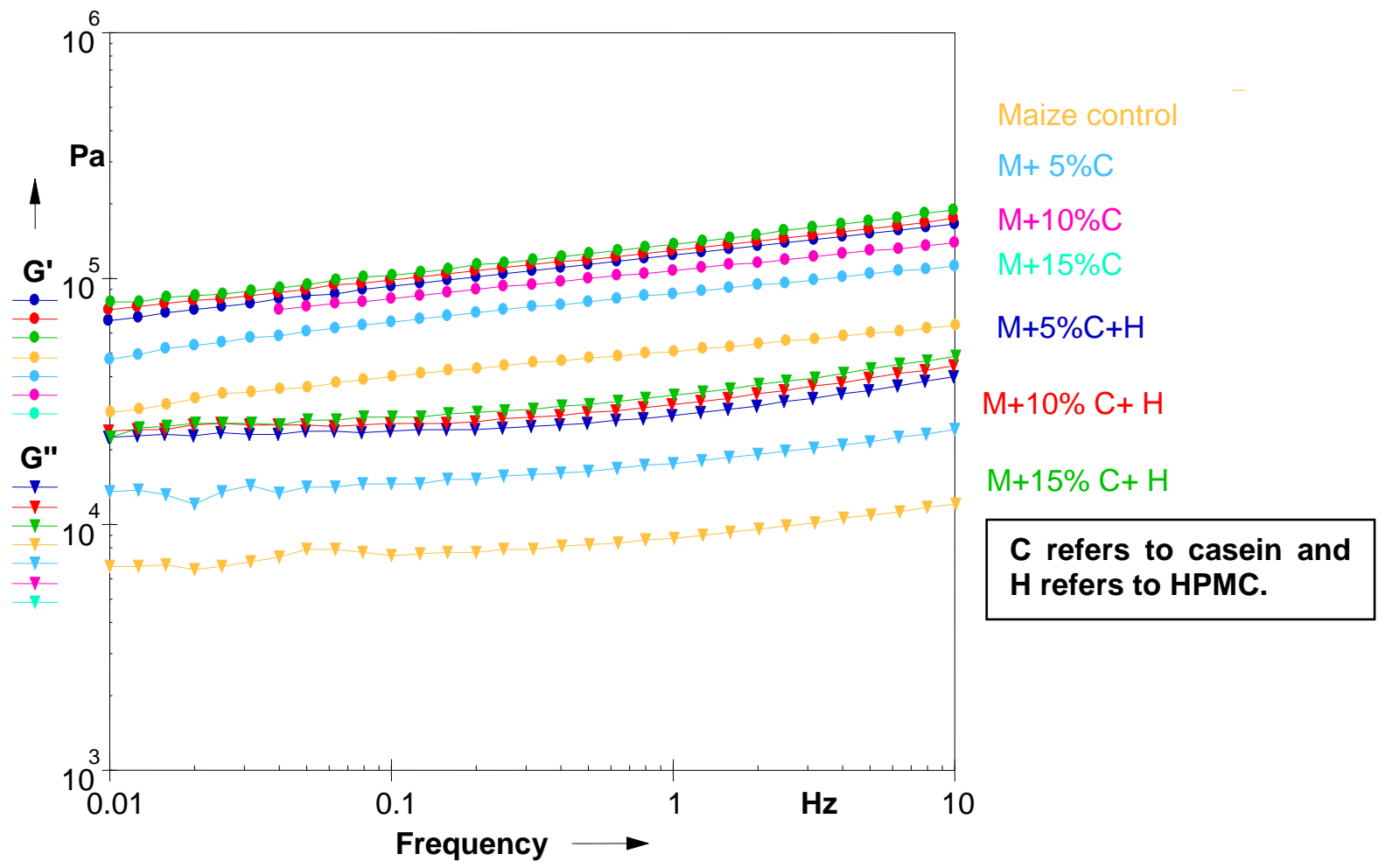

Fig.3 Frequency sweep analysis of QPM flour dough information about $G^{*}$

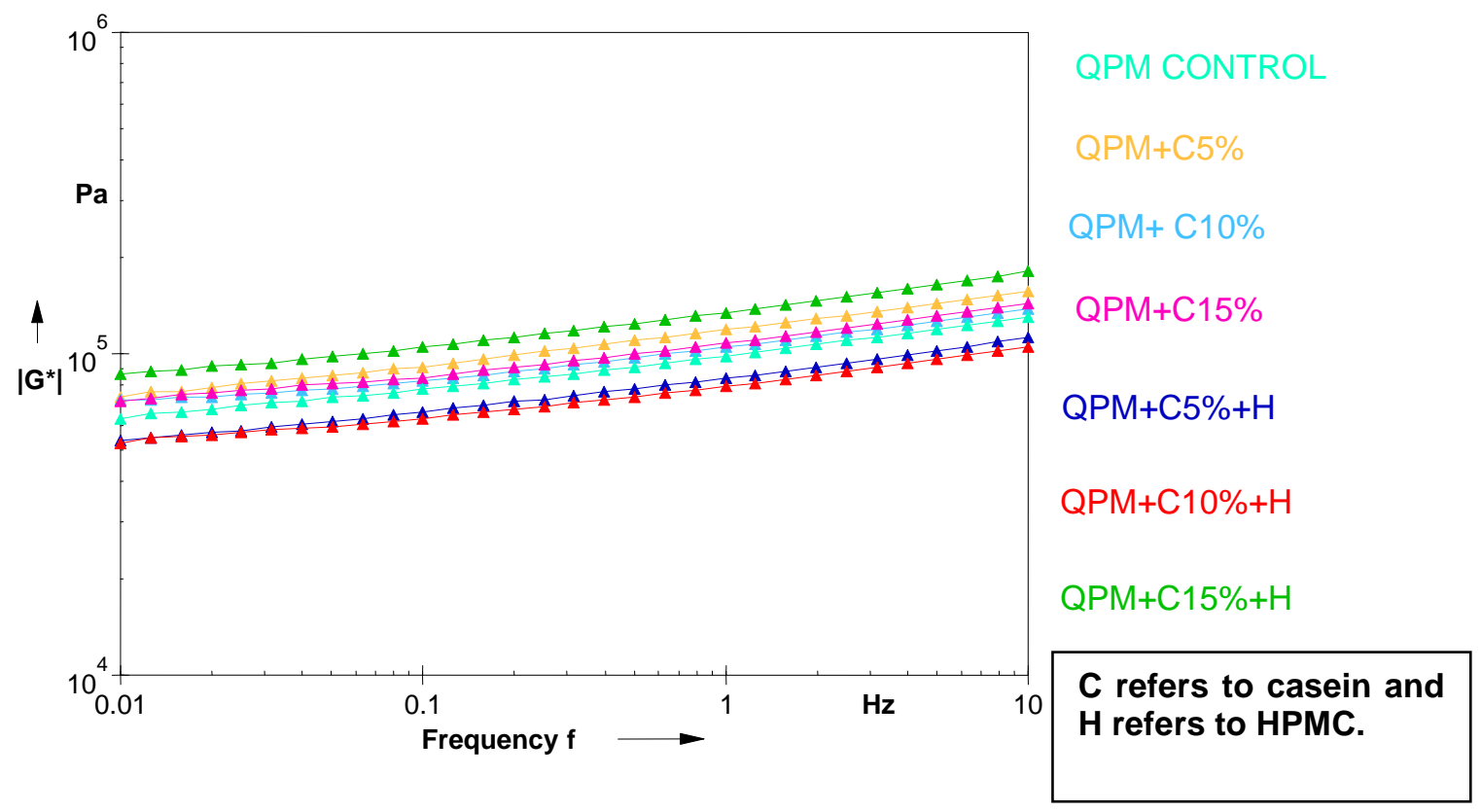


Fig.4 Frequency sweep analysis of maize flour dough giving information about $\mathrm{G}^{*}$

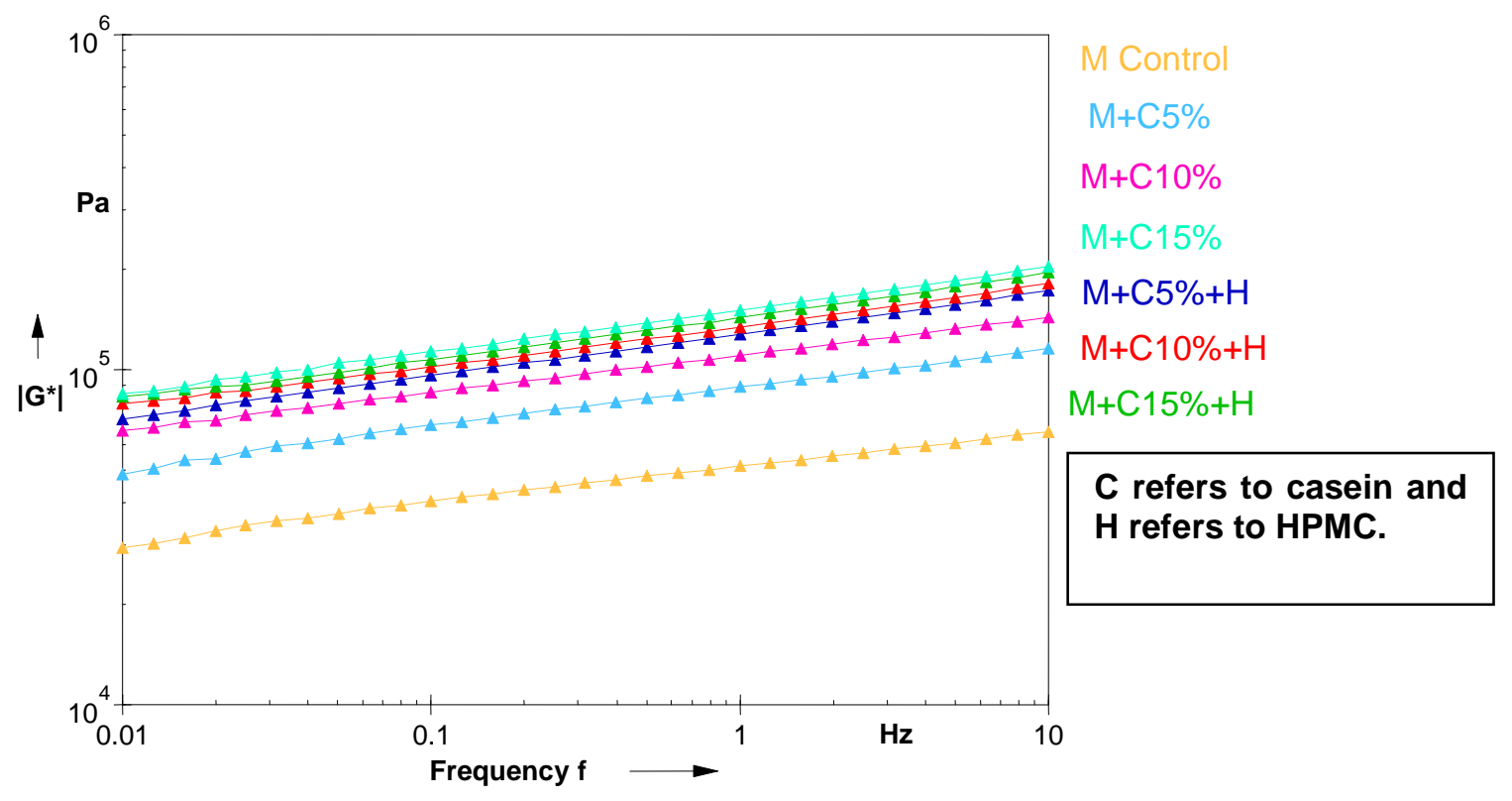

Mechanical spectra of all the tested samples showed that values for storage or elastic modulus $\left(G^{\prime}\right)$ were higher than the values for loss or viscous modulus $\left(\mathrm{G}^{\prime \prime}\right)$ at all the tested frequency range (Fig. 1 and 2), which suggested a solid elastic behavior of the dough samples. It has been reported that low moisture containing corn flour doughs without any added gum showed more viscoelastic solid behavior than samples with higher moisture content and or gum.

As per Lai and Liao (2002) material showing higher values of $\left(G^{\prime}\right)$ could be classified as elastic gels. Addition of protein and hydrocolloid increased the values of dynamic moduli (G') and (G") of dough as compared to control dough which showed that the new hydrophilic and hydrophobic interactions may be developing in the system.

The highest values of storage $\left(G^{\prime}\right)$ and loss $\left(G^{\prime \prime}\right)$ moduli and large difference in their values were observed for maize flour sample containing 15\% casein and QPM flour with $15 \%$ casein and 3\% HPMC and as compared to control, which showed that these flour formulations contributed to a less viscous but more elastic property (Lee and Inglett, 2006). The increase in elastic character is reported to be responsible for shape retention properties during dough handling (Inglett et al., 2013).

The values of loss tangent $(\tan \delta)$ are obtained from the ratio of energy lost to the energy stored $\left(\mathrm{G}^{\prime \prime} / \mathrm{G}^{\prime}\right)$. As compared to maize, tan values were less for QPM dough. In present study QPM flour formulation with 5\% and $10 \%$ casein alone and $10 \%$ casein and $15 \%$ casein with 3\% HPMC and maize flour formulations with $15 \%$ casein alone and with HPMC showed consistency in the value of $\tan$ $\delta$ over a certain frequency range and for all studied samples $\left(\mathrm{G}^{\prime}\right)$ was more than $\left(\mathrm{G}^{\prime \prime}\right)$. It has been suggested that material shows elastic or rubber like behavior if the value of $\left(G^{\prime}\right)$ is independent of frequency and greater than $\left(\mathrm{G}^{\prime \prime}\right)$ over a certain frequency range (Inglett $e t$ 
al., 2013). Therefore, results revealed that addition of casein (10-15\%) in presence of hydrocolloid showed increase in elasticity of dough (Fig. 1 and 2).

The complex modulus $\left(\mathrm{G}^{*}\right)$ gives information (Fig. 3 and 4) about the elasticity and the viscosity of the material; which in turn gives information on the strength of the samples (Fevzioglu et al., 2012). Highest $\mathrm{G}^{*}$ values were obtained for dough with $15 \%$ casein followed by $15 \%$ casein and HPMC in case of maize, while for QPM dough prepared from $15 \%$ casein and HPMC showed highest $G^{*}$ value. Highest $\mathrm{G}^{*}$ values indicated a strong structure compared to the other doughs.

\section{Textural properties of dough and chapati}

It has been reported that textural qualities of dough and chapati directly affect its overall acceptability (Yadav et al., 2008). Addition of casein alone at all studied levels of concentration (5-15\%) did not significantly affect the dough extensibility in QPM and maize flour. However, addition of 3\% HPMC increased the dough extensibility in both QPM and Maize flour blends having casein at different levels (Table 2). The dough extensibility ranged from 3.21-9.06 $\mathrm{mm}$ and 3.51-10.19 $\mathrm{mm}$ for QPM and maize flour blends, respectively. The addition of gum/ hydrocolloid in dough can induce several changes. It can affect the protein network formation, allow dough plasticity and cohesiveness. The maximum force required to rupture the dough was found to increase with addition of casein at all concentrations, with and without HPMC.

In case of chapati samples the force needed to extend the chapati strip increased during extension and reached a maximum before the strip ruptured, followed by a decrease. Control chapaties from QPM and maize showed peak force required to rupture chapaties as $4.35 \mathrm{~N}$ and $4.21 \mathrm{~N}$, respectively and these values decreased significantly with addition of casein (Table 2). The data revealed that chapaties prepared from QPM and Maize flour with addition of casein alone as well as with hydrocolloid were soft in texture as compared to their control samples due to less peak load values.

Extensibility of chapati did not improve on addition of casein and hydrocolloid. Chapati extensibility in QPM and maize ranged from 3.83-4.73 and 3.21-4.21, respectively (Table 2). Although dough extensibility increased significantly with hydrocolloid but increase in chapati extensibility was not observed with addition of hydrocolloid in the presence of protein. This behavior could be correlated with results of Stathopoulos and O'Kennedy (2008) who have reported that aggregated casein samples were more elastic than gluten at room temperature but upon heating produced materials that were weaker and had a predominately viscous character. However, increase in extensibility of wheat flour dough chapati with addition of carboxymethylcellulose (CMC) has been reported (Gujral and Pathak, 2002).

\section{Sensory analysis and nutritional composition}

The sensory analysis of the fresh chapati was performed. This was carried out by 15 semitrained panelists using a 10 point hedonic scale. The chapati prepared from flour with $10 \%$ protein and 3\% HPMC scored highest for QPM as well as maize and showed significant difference from control samples (Table 2). Proximate analysis (Table 3) of chapaties showed that addition of casein alone and casein with HPMC significantly increased the moisture content of chapati. It showed that addition of protein as well as hydrocolloid helped to retain more water and as a result chapaties were more pliable and 
showed lower peak load during texture studies. An inverse relation between rate of firming of chapati and water has also been reported by Roger et al., (1988). As reported by Sahraiyan et al., (2013), the extent of water absorption increases markedly when hydrocolloids are used alone or in combination. Protein content of chapaties increased with increase in concentration of casein. Fat content was slightly less than control chapaties. This slight decrease could be due to increased concentration of protein. Chapati samples with more moisture and protein showed less value for carbohydrate content.

The results revealed that the progressive addition of casein in QPM and maize flour decreased the viscosity parameters significantly and this decrease was dependent on percentage of casein addition. Rheological data revealed that dough containing $15 \%$ casein and HPMC showed highest strength. Dough extensibility studies revealed that addition of HPMC (3\%) along with protein at all concentrations significantly increased extensibility of dough as compared to control. Incorporation of protein and hydrocolloid improved the flours of QPM and maize. Panelists rated the chapaties containing 10\% casein and 3\% HPMC with overall acceptability of (8.20 and 7.90) as compared to control (6.50 and 6.15) for QPM and maize flour, respectively. From the results it can be inferred that a judicious selection of protein and/or hydrocolloid in appropriate levels can develop QPM as well as maize dough that possess the desirable handling properties for preparation of different products.

\section{Acknowledgements}

The authors acknowledge Dr. Ramesh Kumar, Senior Scientist (Plant Breeding), ICARIIMR, Ludhiana for providing QPM and maize grains. Help provided for texture analysis by Dr M.S. Alam, College of Agricultural Engineering, PAU, Ludhiana, facilities and financial support extended by the Director, ICAR-CIPHET, Ludhiana, Punjab (India) and Indian Council of Agricultural Research (ICAR), New Delhi (India) is also acknowledged.

\section{References}

AACC. 1995. American Association of Cereal Chemist, approved methods of the AACC (9th edn.). St. Paul, MN: The Association.

Association of Official Analytical Chemists (AOAC). 2000. Official Methods of Analysis (17 ${ }^{\text {th }}$ edn.) (MD, USA).

BIS. 1971. Indian Standard IS: 6273 Part I and Part II. Guide for sensory evaluation of foods. New Delhi: Indian Standard Institution (BIS), Manak Bhawan.

Dass, S., Jat, M.L., Singh, K.P., and Rai, H.K. 2008. Ago-economic analysis of maize based cropping systems in India. Indian J Fert., 4, 53-62.

Dixit, Y., and Bhattacharya, S. 2015. Rheological and sensory behaviour of rice flour dough: effect of selected additives in relation to dough flattening. J Food Sci. Technol., 52, 4852-4862.

Fevzioglu, M., Hamaker, B. R., and Campanella, O. H. 2012. Gliadin and Zein Show Similar and Improved Rheological Behavior when Mixed with High Molecular Weight Glutenin. $J$ Cereal Sci., 5, 265-271.

Flores-Farias, R., Martinez-Bustos, F., Salinas-Moreno, Y., Chang, Y. K., Hernandez, J. S., and Rios, E. 2000. Physicochemical and rheological characteristics of commercial nixtamalised Mexican corn flours for tortillas. J Sci. Food Agric., 80, 657664. 
Gujral, H. S., and Pathak, A. 2002. Effect of composite flours andb additives on the texture of chapati. J Food Eng., 55, 173-179.

Han, X.Z. and Hamaker, B.R. 2001. Amlyopectin fine structure and rice starch breakdown. J Cereal Sci., 34, 279-284.

Hoover R., Sosulski F.W.1985.Studies on the functional characteristics and digestibility of starches from Phaseolus vulgaris biotypes. Stärke, 37, 181-191.

Huang, C.C., Lin, M.C. and Wang, C.C.R. 2006. Changes in morphological, thermal, and pasting properties of yam (Dioscorea alata) starch during growth. Carbo Poly., 64, 524-531.

Inglett, G. E., Chen, D. and Lee, S. (2013). Rheological Properties of Barley and Flaxseed Composites. Food Nutrit. Sci., 4, 41-48.

Lai L.S., and Liao, C.L. 2002. Dynamic rheology of structural development in starch/decolourised hsian-tsao leaf gum composite systems. J Sci. Food Agric., 82, 1200-1207. DOI: 10.1002/jsfa.1171.

Lee, S. and Inglett, G. E. 2006. Functional characterization of steam jet-cooked $\beta$ Glucan rich barley flour as an oil barrier in frying batters. J Food Sci., 71, E308E313. DOI: $10.1111 / \mathrm{j} .1750$ 3841.2006.00121.x

Leelavathi, K., Indrani, D., \& Sidhu, J. S. 1987. Amylograph pasting behaviour of cereal and tuber starches. Stärke, 39(11), 378-381. http://dx.doi.org/10. 1002/star.19870391103

Matos, M.E., Sanz, T. and Rosell, C.M. 2014 Establishing the function of protein on the rheological and quality properties of rice based gluten free muffins. Food Hydrocoll.

Nimsung, P., Thongngam, M. and Naivikul, O. 2007. Compositions, morphological and thermal properties of green banana flour and starch. Natural Sci., 41, 324330.

Patindola, J., Wanga, Y. J., Jane, J. L. (2005). Structure-functionality changes in starch following rough rice storage. Starch/stärke, 57,197-207 DOI 10.1002/star.200400367.

Rogers, D. E., Zeleznak, K. J., Lai, C. S., and Hoseney, R. C. 1988. Effect of native lipids, shortening, and bread moisture on bread firming. Cereal Chem., 65, 398.

Saha S, Bhattacharya S.2010. Hydrocolloids as thickening and gelling agents in food: a critical review. J Food Sci. Technol., 47, 87-597. doi: 10.1007/s13197-0100162-6.

Sahraiyan B, Naghipour F, Karimi M, Davoodi, M.G.2013. Evaluation of Lepidium sativum seed and guar gum to improve dough rheology and quality parameters in composite rice-wheat bread. Food Hydrocoll. 30, 698-703. doi: 10.1016/j.foodhyd.2012.08.013.

Sandhu, K.S., and Singh, N. 2007. Some properties of corn starches II: physicochemical, gelatinization, retrogradation, pasting and textural properties. Food Chem., 101, 14991507.

Sandhu, K.S., Singh, N., Malhi, N.S. 2007. Some properties of corn grains and their flours I: Physicochemical, functional and chapati-making properties of flours. Food Chem., 101, 938-946.

Sarabhai, S. and Prabhasankar, P. 2015.Influence of whey protein concentrate and potato starch on rheological properties and baking performance of Indian water chestnut flour based gluten free cookie dough. LWT-Food Sci. Technol., 63:1301-1308.

Sciarini, L.S., Ribotta, P D., Leon A. E., and Perez, G. T. 2012. Incorporation of several additives into gluten free breads: 
Effect on dough properties and bread quality. J Food Eng., 111, 590-597.

Stathopoulos, C.E., and O'Kennedy, B.T. 2008. A Rheological Evaluation of Concentrated Casein Systems as Replacement for Gluten: Calcium Effects. Int. J Dairy Technol., 61 (4), 397-402.

Steffe, J.F. 1996. Rheological Methods in Food Process Engineering, second ed. Freeman Press, USA, pp. 324e336.

Tester, R F., and Morrison, W. R. 1990. Swelling and gelatinization of cereal starches. I. Effects of amylopectin, amylose, and lipids. Cereal Chem., 67,551-55.

Yadav, D. N., Patki, P.E., Mahesh, C., Sharma, G.K., and Bawa, A.S. (2008) Optimization of baking parameters of chapati with respect of vitamin B1 and B2 retention and quality. Int. J Food Sci. Technol., 43:1474-1483.

Ylimaki G, Hawrysh ZJ, Hardin RT, Thomson ABR 1988. Application of response surface methodology to the development of rice flour yeast breads: Objective measurements. $J$ Food Sci. 1988; 53:1800-1805. doi: 10.1111/j.1365-2621.1988.tb07846.x

\section{How to cite this article:}

Manju Bala, Arun Kumar, S.K. Nanda and Gupta, R.K. 2018. Effect of Casein and Hydrocolloid on Maize Dough and Chapati Properties. Int.J.Curr.Microbiol.App.Sci. 7(04): 2058-2070. doi: https://doi.org/10.20546/ijcmas.2018.704.236 